Sandra G. L. Schruijer*

\title{
Do Women Want to Break the Glass Ceiling? A Study of their Career Orientations and Gender Identity in The Netherlands ${ }^{* *}$
}

Career orientations, career success and perceived self-efficacy of women employees in relation to their gender identity were studied. It was hypothesized that gender identity is related to career orientations such that women with a masculine gender identity strive for more upward mobility as compared to women with a feminine gender identity, whereas the latter strive more for balancing work and private life. A masculine gender identity was furthermore predicted to be positively related to career success in terms of income and hierarchical position. Finally it was expected that women with a feminine gender identity, in comparison to those with a masculine gender identity, express a lower self-efficacy with respect to stereotypical male and gender-neutral tasks and equal self-efficacy with respect to stereotypical feminine tasks. To test the hypotheses, a questionnaire was distributed among women working for a large multinational corporation. The results provided support for the first two hypotheses. Mixed support was obtained for the third hypothesis.

Key words: Gender Identity, Career Orientations

* Sandra Schruijer, Utrecht School of Governance, Utrecht University, Bijlhouwerstraat 6, 3511 ZC Utrecht, The Netherlands, e-mail: s.schruijer@usg.uu.nl.

** Article received: October 21, 2005

Revised version accepted after double blind review: April 19, 2006.

management revue, 17(2): 143-154 


\section{Introduction}

Many women have entered the labor market and occupy management positions. Only sporadically however do they reach top management and/or board positions. The phenomenon called the 'glass ceiling' (Morrison/White/Van Velsor 1987) still exists in many western countries (Powell 1999), including The Netherlands (Sociaal Cultureel Planbureau 2000). Several explanations for this phenomenon have been offered. Human capital theory for instance, states that shortcomings on the part of women (education, experience) make them less suitable for top positions. Other explanations refer to stereotyping and prejudice, the existence of a dual labor market, and, the career orientations of women themselves. This study focuses on women's career orientations. Its aim is to obtain a better understanding of women's career orientations by testing relationships between gender identity, career orientations and career success.'Career orientation' can be described as an individual's preferences, values and ideas concerning his or her career; it refers to one's career goals and ideals and the priority they have in one's life as well as the rank ordering among different goals. Derr (1988) distinguished five career types, namely, 'getting ahead', where reaching the top is dominant, 'getting secure', where security and predictability are key in one's career choices, 'getting free', for those who value autonomy, 'getting high', representing striving for challenging work and self-realization, and finally, 'getting balanced', where the balance between work and private life is central. Family concerns are likely to have a stronger impact on women's career choices than on those of men. Based on an extensive literature study with which she tries to understand the implications of genderbased differences rather than their causes, Gallos (1995) reasons that relationships, attachment and caring are central to the lives of women. Therefore, their career choices are more likely to make an integration between work and family possible, i.e. balancing the demands posed by both. For men, independence, autonomy and centrality of work in their lives are more characteristic. Upward mobility for men is a more important career goal than for women. Several studies indeed show that women's career preferences are less aligned with 'getting ahead' than those of men (Manhardt 1972; Taillieu 1994, Power/Butterfield 2003).

The current study addresses the career orientations of women, but, instead of studying sex differences, we will focus on gender identity and its relationship to career orientations and career success. Sex refers to the categories of 'male' and 'female', whereas the term gender is used to express how individuals perceive or define themselves or are perceived by others (Deaux 1985). In other words, "sex' is a biological term and 'gender' a psychological and cultural one" (Oakley 1972: 158). Or, as phrased by Unger and Crawford, 'gender is what culture makes of the raw material of biological sex' (1992: 18). Gender identity is "that part of one's self concept that is influenced by cultural prescriptions concerning the appropriate attributes of women and men" (Rojahn 1996). People differ with respect to the extent in which they individually have internalized culturally defined roles, behaviors and attitudes, which are (stereotypically) associated with either sex. These individual differences have been expressed in terms of psychological masculinity and femininity (Bem 1974), instrumentality and expressiveness (Spence/Helmreich 1978), or, self-assertion and nurturance (Deaux 1985). 
Within social psychology a research tradition has been established working with Bem's conceptualization of gender identity. Bem conceives of masculinity and femininity as two independent dimensions; they are not opposites of one another. As a consequence, men and women can have comparable gender identities: masculine (high on masculinity, low on femininity), feminine (high on femininity, low on masculinity), androgynous (high on masculinity and high on femininity), or undifferentiated (low on masculinity and low on femininity). Research has shown that gender identity predicts individuals' personalities, attitudes and behavior better than sex (Cook 1985; Van Engen 2001). Kent and Moss (1994) demonstrated that group members with masculine characteristics were more likely to emerge as leaders than group members with any of the other three gender types (feminine, androgynous, undifferentiated). Further, there is evidence that femininity is related to a people-oriented leadership style whereas masculinity is related to a task oriented leadership style (Korabik 1982).

A variety of studies have shown that masculinity is positively related to women's career development in terms of career achievement, performance self-esteem, and, willingness to pursue nontraditional careers (Betz/Fitzgerald 1987; Power/Butterfield 2003). It is likely that women who are strongly career-oriented are more similar to strongly career-oriented men rather than other women. Manhardt (1972) for example showed that male college graduates rated job characteristics pertaining to advancement (e.g. opportunity to earn a high income, supervising others) higher than female graduates who rated working conditions and leisure time off the job as more important. "When the female sample was restricted to only those who rated a career first among their major life satisfactions, the sex differences, including those in job characteristics not directly related to career orientation (e.g., working with people) were almost completely eliminated" (Manhardt 1972: 367).

We expect differences between women with a masculine identity on the one hand and those with a feminine identity on the other such, that women with a feminine identity will pursue 'getting balanced' more than those with a masculine identity yet 'getting ahead' less. Our first hypothesis therefore is:

1. Women's career orientations are related to their gender identity, such that women with a masculine identity strive more for upward mobility as compared to women with a feminine identity, while women with a feminine identity pursue more balance than those with a masculine identity.

If indeed women with a masculine identity strive more to get ahead, we also expect these women more likely to be a manager, to have higher salaries and to have reached higher hierarchical positions than women with a feminine identity (Fagenson 1990; Kent/Moss 1994):

2. Women with a masculine identity are more likely to occupy a managerial position as compared to those with a feminine identity, and, are likely to be more successful in their careers as measured by income and hierarchical position.

Another variable that is related to gender and career aspirations (and subsequent career choice) is perceived self-efficacy. It has been found that career and occupational choice is affected by the expectations one has with respect to being successful in a particular career or occupation (Betz/Hackett 1981). Self-efficacy in this context re- 
fers to the beliefs one has that one can perform successfully in a certain work domain or in a certain career. Several studies relate perceived self-efficacy among men and women to the gender-typed nature of the task or career option (Eccles, Adler/Meece 1984). Bridges (1988) for instance showed that women expressed lower self-efficacy expectations for masculine and gender-neutral occupations than for feminine occupations; self-efficacy of the male respondents however did not differ for the three types of occupations. Eccles (1994) links gender role beliefs to expectations of success. Activities and aspirations that do not fit the gender role may be rejected because they may be seen as unattainable or uninteresting. In line with the latter line of reasoning, we expect that women with a masculine identity will express a higher self-efficacy for stereotypical masculine and neutral work domains, whereas women with a feminine identity will have similar self-efficacy expectations for stereotypical feminine work domains as those with a masculine identity. Therefore, we hypothesize that

3. Perceived self-efficacy is related to gender identity and stereotypicality of task, such, that women with a feminine identity have a lower self-efficacy with respect to stereotypical masculine and gender-neutral tasks as compared to women with a masculine identity, and, women with a feminine identity are equal in their selfefficacy as women with a masculine identity on stereotypical feminine tasks.

\section{Method}

\section{Instrument}

A questionnaire was developed which tapped career orientations, gender identity and self-efficacy. 17 items were formulated intended to measure each of Derr's career orientations, namely 'getting ahead' (e.g. reaching the top), 'getting secure' (e.g. a predictable and secure career with one organization, 'getting free' (e.g. being one's own boss), 'getting high' (e.g. high challenge in one's work, and 'getting balanced' (e.g. creating the right balance between work, family, friends and self-realization). Respondents were asked to indicate to which extent they wanted to realize each of these 17 career goals $(1=$ to a very small extent; $7=$ to a very large extent). Factor analysis revealed six factors (see Appendix), four of which directly could be related to Derr's career types and had sufficiently high alphas, namely:

- ' 'getting balanced' (having enough time for work and private life; creating the right balance between work, family, friends and self-development; harmony between leisure, career and family; $\alpha=.80$ );

- 'getting high' (having the biggest possible challenge from work; being able to attain self-realization; being creative and innovative; $\alpha=.65)$;

- ' 'getting free' (complete autonomy over my own work; being my own boss; being independent from others in my work; $\alpha=.73$ );

- ' 'getting ahead' (reaching the top; acquiring a lot of power and influence; $\alpha=.89$ ). Gender identity was measured using a Dutch version of Bem's Sex-Role Inventory (Bem 1974)1. The BSRI consists of sixty adjectives of which twenty are masculine and

1 Translated by Dr. M. Bekker, University of Amsterdam and University of Tilburg. 
twenty feminine. Respondents had to indicate the extent to which each of them applied to themselves. Based on a median-split the total group of respondents was categorized as having a masculine identity (above the median for masculine adjectives and below the median for feminine adjectives), a feminine identity (below the median for masculine adjectives and above the median for feminine adjectives), an androgynous identity (above the median for masculine adjectives and above the median for feminine adjectives) or being undifferentiated (below the median for masculine adjectives and below the median for feminine adjectives). We will confine ourselves to the comparison between those with a masculine and feminine identity.

Respondents' self-efficacy was assessed by asking them to what extent they found themselves suitable for eleven work domains $(1=$ to a very small extent; $7=$ to a very large extent): personnel, marketing, development, production, top management, finance, sales, logistics, public relations, administration, consultancy. By also asking for the extent to which men and women were found to be suitable for each work domain, we could determine the gender-typing of each domain.

Finally, the respondents were asked for some background information, namely their current salary (ranging from 40 to 80 ), their hierarchical position, measured by asking for a subjective estimate expressed on a 7-point scale ranging from very low (1) to very high (7)), age, work experience (in years), number of years working for the company, number of subordinates, number of children, their marital status and level of education.

\section{Respondents}

The questionnaire was sent to all female employees $(n=621)$ with an academic or polytechnic education, within a certain geographical region of a large electronics firm in The Netherlands. 167 women responded (27\%). Forty-four of them occupied a managerial position. The respondents' mean age was 35.2 years, whereas the average working experience amounted to twelve years (eleven years was the mean for working with the firm). 124 respondents were either married or living with a partner. 115 had no children; 48 had one or more children. Sixty possessed a university degree and seventy-six completed a polytechnic education. The data was collected in 1994.

\section{Results}

For the four career types ('getting ahead', 'getting high', 'getting free' and 'getting balanced') t-tests for independent samples were performed in order to compare the means of respondents with a masculine identity and those with a feminine identity. Ttests were also used for testing differences with respect to salary, hierarchical position, number of years of working experience, of working experience at the company, and finally, age. The results are shown in Table 1:

From Table 1 it can be read that women with a feminine identity found 'getting balanced' more important than women with a masculine identity, whereas the latter found 'getting ahead' less unimportant than women with a feminine identity. Finally, women with a masculine identity earned more, rated themselves higher in hierarchical position, and, were older. 
Table 1: Career orientations, salary, hierarchical position, work experience, experience with the company and age for the total group of respondents, for women with a feminine identity and for women with a masculine identity ${ }^{2}$

\begin{tabular}{|c|c|c|c|c|c|}
\hline & $\begin{array}{c}\text { all } \\
\mathrm{n}=167\end{array}$ & $\begin{array}{c}\text { identity } \\
\text { feminine } \\
n=37\end{array}$ & $\begin{array}{c}\text { identity } \\
\text { masculine } \\
\mathrm{n}=35\end{array}$ & $d f$ & $t$ \\
\hline getting balanced & 6.28 & $6.50^{\mathrm{a}}$ & $5.91^{\mathrm{a}}$ & 70 & $2.84^{* *}$ \\
\hline getting high & 5.78 & $5.68^{\mathrm{b}}$ & $5.92^{\mathrm{a}}$ & 70 & -1.22 \\
\hline getting free & 4.63 & $4.32^{c}$ & $4.88^{b}$ & 70 & -1.79 \\
\hline getting ahead & 3.06 & $2.34^{d}$ & $4.00^{C}$ & 70 & $-4.92^{* * *}$ \\
\hline salary & 55.10 & 52.70 & 59.00 & 70 & $-2.59^{*}$ \\
\hline hierarchical position & 3.99 & 3.89 & 4.50 & 69 & $-2.41^{*}$ \\
\hline years working & 12.01 & 11.59 & 13.69 & 67 & -1.04 \\
\hline years company & 10.81 & 10.49 & 13.25 & 70 & -1.55 \\
\hline age & 35.21 & 33.89 & 37.80 & 70 & $-2.29^{*}$ \\
\hline
\end{tabular}

Chi-square analyses of gender identity on the one hand and parenthood, marital status, being a manager or not (i.e. having subordinates), and, having a university or a polytechnic education on the other hand, only revealed a significant association for gender identity and being a manager $\left(\chi^{2}(1)=17.5 ; \mathrm{p}<.001\right)$ : sixteen women with a masculine identity were not a manager whereas nineteen women with a masculine identity were. Only three women with a feminine identity were a manager as opposed to thirty-three not.

The left hand side of Table 2 reflects the means for the perceived suitability of men and of women for working in the eleven domains. For this analysis only women with either a feminine or masculine identity were selected (using analyses of variance, no main effects of gender identity were found. Only one interaction effect between target and identity was obtained, namely, for sales). As can be seen, stereotypical male domains (i.e. a statistically significant difference between the perceived suitability of men and women was established using t-tests for paired samples) were development and production; stereotypical female domains were personnel, public relations and administration. The right hand side of the table provides the differences in the perceived suitability of self between women with a masculine identity and those with a feminine identity. Women with a masculine identity assessed their suitability for marketing, top management, finance, sales and consultancy higher than the feminine women did. Women with a masculine identity had a higher average self-efficacy score (a newly constructed variable, resulting from the average perceived suitability for eleven domains) than the women with a feminine identity.

2 The differences between women with a feminine identity and those with a masculine identity have been tested ( $\mathrm{t}$-test for independent samples). The strength of each career orientation has been compared among the two identity groups separately (t-test for paired samples; column means that do not share a superscript differ significantly from each other). 
Table 2: Perceived suitability of men and women for various work domains, and, the perceived suitability of self as assessed by women with a feminine identity and by women with a masculine identity (means)

\begin{tabular}{|c|c|c|c|c|c|c|c|c|}
\hline & $\begin{array}{c}\text { target } \\
\text { women }\end{array}$ & $\begin{array}{c}\text { target } \\
\text { men }\end{array}$ & $\mathrm{df}$ & $t$ & $\begin{array}{l}\text { identity } \\
\text { feminine }\end{array}$ & $\begin{array}{c}\text { identity } \\
\text { masculine }\end{array}$ & $\mathrm{df}$ & $t$ \\
\hline personnel & 6.27 & 5.56 & 63 & $4.43^{\text {tats }}$ & 4.64 & 4.34 & 69 & 0.74 \\
\hline marketing & 6.23 & 5.98 & 63 & 1.98 & 4.11 & 4.97 & 69 & $-2.14^{*}$ \\
\hline development & 5.97 & 6.36 & 63 & $-3.34^{\text {t*t/ }}$ & 4.58 & 3.94 & 68 & 1.34 \\
\hline production & 5.86 & 6.30 & 63 & $-3.15^{* *}$ & 3.97 & 4.06 & 68 & -0.19 \\
\hline $\begin{array}{l}\text { top } \\
\text { management }\end{array}$ & 6.19 & 6.17 & 63 & 0.24 & 2.97 & 4.74 & 68 & $-4.53^{*+*}$ \\
\hline finance & 6.14 & 6.20 & 63 & -0.78 & 3.50 & 4.71 & 69 & $-2.86^{* t}$ \\
\hline sales & 6.08 & 6.20 & 63 & -1.27 & 3.03 & 4.31 & 69 & $-3.31^{\text {t"tw }}$ \\
\hline logistics & 6.16 & 6.17 & 63 & -0.18 & 4.81 & 4.43 & 69 & 0.91 \\
\hline $\begin{array}{l}\text { public } \\
\text { relations }\end{array}$ & 6.41 & 5.89 & 63 & $4.38^{\text {*t+ }}$ & 4.25 & 4.57 & 69 & -0.77 \\
\hline administration & 6.20 & 6.02 & 63 & $2.35^{*}$ & 4.36 & 4.51 & 69 & -0.35 \\
\hline consultancy & 6.23 & 6.06 & 63 & 1.96 & 4.11 & 5.50 & 68 & $-4.14^{-\ldots+m}$ \\
\hline $\begin{array}{l}\text { average } \\
\text { self-efficacy }\end{array}$ & 6.16 & 6.08 & 63 & $2.12^{*}$ & 4.03 & 4.56 & 66 & $-2.73^{* *}$ \\
\hline
\end{tabular}

${ }^{*}<<.05^{* *} p<.01 \quad{ }^{* * *} p<.001$

Subsequently regression analyses were performed, using two identity measures namely, the average score on the masculine items combined, and, the average score on the femininity items combined. Thus we could address the hypotheses among the total sample of 167 women and simultaneously assess the importance of background variables like education, marital status, years of working experience and age. The dependent variables were the four career orientations, salary, hierarchical position, and, average self-efficacy. Predictors were masculinity, femininity, managerial status $(0=$ no manager; 1 = manager), years of working experience, years with the company, age, parenthood $(0=$ no parent, $1=$ parent $)$, marital status $(0=$ unmarried / cohabiting/ divorced/ widowed; $1=$ married $)^{3}$, education $(0=$ education below university level; 1 $=$ university degree). The results are presented in Table 3:

Controlling for various background variables, femininity had a positive contribution to 'getting balanced', whereas masculinity contributed positively to 'getting ahead', as expected. Masculinity was positively related to 'getting high'. Both masculinity and femininity were positively associated with 'getting free'. Salary was strongly accounted for by education (and less so by age). Still, femininity had a unique negative contribution. Masculinity was positively related to hierarchical position and self-efficacy.

3 Cohabiting women were categorized with the unmarried and other single women, as is commonly done. Creating a variable in which cohabiting respondents were put in the same category as the married women did not change the results. 
Table 3: Regression coefficients $(\beta)$ of femininity, masculinity and background variables in predicting career orientations, salary, hierarchical position and self-efficacy

\begin{tabular}{|l|c|c|c|c|c|c|c|}
\hline indep. & ahead & free & high & balance & salary & hierarchy & self-efficacy \\
\hline femininity & & $.17^{*}$ & & $.24^{* *}$ & $-.24^{* * *}$ & & \\
\hline masculinity & $.41^{* * *}$ & $.31^{* * *}$ & $.42^{* * *}$ & & & $.27^{*}$ & $.40^{* * * *}$ \\
\hline age & & & $.27^{* * *}$ & & & $.22^{* * *}$ & \\
\hline years working & & & $-.18^{*}$ & $-.17^{*}$ & & & \\
\hline education & & & & & $.70^{* * *}$ & & \\
\hline Adj. $\mathrm{R}^{2}$ & .16 & .16 & .21 & .09 & .62 & .07 & .15 \\
\hline
\end{tabular}

$\mathrm{p} p<.05^{* *} p<.01 \quad{ }^{* * *} p<.001$

\section{Discussion}

Overall, the most important career orientation of the participating 167 women was 'getting balanced', whereas the least attractive career goal was 'getting ahead' $(\mathrm{M}=$ 6.28 and $\mathrm{M}=3.06$ respectively). The little importance of 'getting ahead' for women is in line with a study by White, Cox and Cooper (1994), who tapped Derr's career orientations among 48 women whom they classified as highly successful. They found that, strangely enough, none of them strove for 'getting ahead' (which they explain by the fact that most were already at the top), 31\% wanted to 'get secure', $15 \%$ strove for 'getting free', while $48 \%$ expressed a career orientation in line with 'getting high'. Contrary to our findings, these successful women did not find 'getting balanced' very important; work played a central role in their lives. Was that so because these highly successful women perhaps tended not to have a family (even among our sample of 167 women, 36 were single (with an average age of 34.4 years of age, while 89 were married (average age of 35.7) with only 40 of them having children)? In line with hypothesis 1 women with a masculine identity strove more for 'getting ahead' as compared to women with a feminine identity $(\mathrm{M}=4.00$ and $\mathrm{M}=2.34$ respectively), while women with a feminine identity strove more for 'getting balanced' than women with a masculine identity $(M=6.50$ and $M=5.91$ respectively).

The dimension of masculinity was positively related to 'getting ahead' while the dimension of femininity was unrelated to this career orientation; a finding consistent with Powell and Butterfield (2003). Masculinity further proved to be positively related to 'getting high'. Both masculinity and femininity contributed positively to 'getting free'; this career orientation therefore may be especially important for women with an androgynous identity. A final difference between women with a feminine identity and those with a masculine identity was, that the former seemed to be more focused in what they want to achieve and what they do not want to achieve: they strongly wanted to have balance and strongly not wanted to get ahead. The scale for the women with a masculine identity was more compressed: all four career orientations were on the positive end of the scale but never so positive as 'getting balanced' was for the women with a feminine identity. 
Hypothesis 2 was confirmed as women with a masculine identity had a higher salary and assessed themselves as having a higher position as compared to those with a feminine identity. Interestingly, it was femininity and not masculinity that was related to salary. We realize that career success for feminine women is not likely to be reflected in the same measures as that of masculine women. Position and salary quite often have been used as the operationalizations of career success in career studies (e.g. Melamed 1996). We acknowledge the male-bias of these particular operationalizations, but exactly for this reason did we expect differences between masculine and feminine women. The higher one goes up the hierarchy the more likely one has the position of a manager. It indeed appeared that those with a masculine identity were more likely to be a manager as compared to those with a feminine identity (cf. Wong/Kettlewell/Sproule 1985). The causality however remains unclear: are women socialized in (male-dominated) organizations into becoming more male-oriented, i.e. do they change their gender identity in the process? Are women with a masculine identity selected by the organization over those with a feminine identity? Do they select themselves when and if applying for higher positions? The current data cannot provide any conclusive answer to these questions.

Hypothesis 3 predicted that women with a feminine identity have a lower selfefficacy with respect to stereotypical masculine and gender-neutral while having an equal assessment of their self-efficacy on stereotypical feminine tasks, as compared to women with a masculine identity. Of the eleven work domains two were perceived as more suitable for women and two as more suitable for men. Interestingly, no differences between the self-efficacy of women with a feminine identity on the one hand and a masculine identity on the other were obtained for these domains. However, for the other domains in which no differential suitability for men and women was perceived, women with a masculine identity did express a higher suitability of self as compared to those with a feminine identity.

For three of the domains in which a difference between women with a masculine and a feminine identity was found (top management, finance, sales), it seems that the women with a feminine identity assessed themselves as not suitable (a mean below the midpoint of the scale), whereas for one domain (consultancy) the women with a masculine identity seemed to inflate their suitability. In trying to disentangle the separate relations of self-efficacy with the femininity dimension and with the masculinity dimension, correlation coefficients were computed between the femininity and masculinity scores on the one hand and self-efficacy for the eleven domains on the other. A positive correlation was obtained between masculinity and seven work domains, whereas no correlation was found between femininity and self-efficacy. Thus, it is the masculinity dimension that was related to self-efficacy. This finding is in line with the study of Long (1989), who showed that women high on masculinity were higher in self-efficacy than those low on masculinity regardless of the occupational role they occupied (traditional vs. nontraditional). ${ }^{4}$

4 Long raises the issue whether masculinity and self-efficacy are overlapping concepts. We inserted self-efficacy as a separate predictor, along with masculinity and femininity and the background variables, in a regression analysis with the career orientations as criteria. It 
Hypothesis 3 was not confirmed when considering stereotypical male domains. It was surprising that domains like top management and finance were not stereotyped as masculine domains. Overall, the differences between the perceived suitability of men and women for the various domains were quite small (and overall even in favor of women as the (slight) difference in average self-efficacy shows!). This may be due to the fact that our sample consisted of highly educated women with good positions. They may have been very aware of their minority position in a strongly malepopulated organization, especially where higher positions are concerned. By denying or minimizing a difference in suitability between men and women in different work domains, they perhaps expressed their conviction that there is no legitimate basis for women being in a minority position at the levels they were working at or at higher levels they were aspiring to.

When looking back at the current study some strengths and weaknesses can be noted. A strength is the sample that was employed. Not consisting of students or young graduates as so often is the case in psychological research, also when gender and organizational behavior is concerned. It has been shown for example that leadership styles of male and female managers differ from those of male and female students (Eagly/Johnson 1990; Korabik/Baril/Watson 1993). However, this sample was not likely to be representative for 'women at work' either. It concerned a sample with highly educated women, who worked on average almost eleven years for the same organization. One may suspect that these women have somehow adapted themselves to the culture of that organization. Nevertheless, the fact that they have associated themselves into an informal network within the organization may indicate their need for mutual support. Being expected to adapt to a male-dominated environment (Loden 1985), while also being expected to be feminine (Eagly/Wood/Diekman 2000) is stressful and has consequences for career advancement (Gardiner/Tiggemann 1999).

\section{References}

Bem, S.L. (1974): The measurement of psychological androgyny. In: Journal of Consulting and Clinical Psychology, 42: 155-162.

Betz, N./Fitzgerald, L. (1987): The career psychology of women. Orland: Academic Press.

Betz, N./Hackett, G. (1981): The relationship of career-related self-efficacy expectations to perceived career options in college women and men. In: Journal of Counseling Psychology, 28: 399-410.

Bridges, J. (1988): Sex differences in occupational performance expectations. In: Psychology of Women Quarterly, 12: 75-90.

Cook, E.P. (1985): Psychological androgyny. New York: Pergamon.

Deaux, K. (1985): Sex and gender. In: Annual Review of Psychology, 36: 49-81.

Derr, C.B. (1988): Managing the new careerists. San Francisco: Jossey-Bass.

Eagly, A./Johnson, B. (1990): Gender and leadership style: A meta-analyis. In: Psychological Bulletin, 108: 233-256.

Eagly, A./Wood, W./Diekman, A. (2000): Social role theory of sex differences and similarities: A current appraisal. In: T. Eckes/H. Trautner (Eds.): The developmental social psychology of gender. Mahwah, NJ: Erlbaum: 123-174.

appeared that self-efficacy had a unique and significant contribution to 'getting ahead' $(\beta=.25)$ and 'getting high' $(\beta=.20)$, apart from masculinity that also had a positive contribution in explaining these career orientations. The concepts thus overlap but are not similar. 
Eccles, J. (1994): Understanding women's educational and occupational choices. In: Psychology of Women Quarterly, 18: 585-609.

Eccles, J., Adler, T./Meece, J. (1984): Sex differences in achievement: A test of alternate theories. In: Journal of Personality and Social Psychology, 46: 26-43.

Engen, M. van. (2001): Gender and leadership: A contextual perspective. PhD dissertation, University of Tilburg, The Netherlands.

Fagenson, E. (1990): Perceived masculine and feminine attributes examined as a function of individuals' sex and level in the organizational power hierarchy: A test of four theoretical perspectives. In: Journal of Applied Psychology, 75: 204-211.

Gallos, J.V. (1995): Exploring women's development: Implications for career theory, practice, and research. In: M. Arthur, D. Hall/B. Lawrence (Eds.): Handbook of career theory. Cambridge: Cambridge University Press.

Gardiner, M./Tiggemann, M. (1999): Gender differences in leadership style, job stress and mental health in male- and female dominated industries. In: Journal of Occupational and Organizational Psychology, 2: 301-315.

Kent, R.L./Moss, S.E. (1994): Effects of sex and gender role on leader emergence. In: Academy of Management In: Journal, 37: 1335-1346.

Korabik, K. (1982): Sex-role orientation and leadership style. In: International Journal of Women's Studies, 5: 328-330.

Korabik, K., Baril, G./Watson, C. (1993): Managers' conflict management style and leadership effectiveness: The moderating effects of gender. Sex Roles, 29, 405-420.

Larwood, L./Gutek, B. (1987): Working toward a theory of women's career development. In B. Gutek/L. Larwood (Eds.): Women's career development. Newbury Park: Sage: 170-183.

Loden, M. (1985): Feminine leadership: Or how to succeed in business without being one of the boys. New York: Times Books.

Long, B. (1989): Sex-role orientation, coping strategies, and self-efficacy of women in traditional and nontraditional occupations. In: Psychology of Women Quarterly, 13: 307-324.

Manhardt: (1972): Job orientation of male and female college graduates in business. In: Personnel Psychology, 25: 361-368.

Melaned, T. (1996): Validation of a stage model of career success. In: Applied Psychology: An International Review, 45, 35-65.

Morrison, A./White, R.P./Van Velsor, E. (1987): Breaking the glass ceiling. Reading, Mass.: AddisonWesley.

Oakley, A. (1972): Sex, gender and society. London: Maurice Temple Smith.

Powell, G. (1999): Reflections on the glass ceiling. In: G. Powell (Ed.): Handbook of gender and work. Thousand Oaks, CA: Sage Publications.

Powell, G./Butterfield, D. (2003): Gender, gender identity, and aspirations to top management. Women in Management Review, 18: 88-96.

Rojahn, K. (1996): Gender in the context of leadership. Enschede: Copyprint 2000.

Sociaal Cultureel Planbureau / Centraal Bureau voor de Statistiek (2000): Emancipatiemonitor.

Spence, J./Helmreich, R. (1978): Masculinity and femininity: their psychological dimensions, correlates and antecedents. Austin: University of Texas Press.

Taillieu, T. (1994): Human resources in transnational assignments: Young graduates looking for transnational careers. In: J.J.J. van Dijck/J. Groenewegen (Eds.): Changing business systems in Europe. Brussel: VUB Press.

Unger, R./Crawford, M. (1992): Women and gender: A feminist psychology. New York: McGraw-Hill.

White, B., Cox, C./Cooper, C. (1994): Women's career development: A study of high flyers. Oxford: Blackwell.

Wong, P., Kettlewell, G./Sproule, C. (1985): On the importance of being masculine: Sex role, attribution, and women's career achievement. In: Sex Roles, 12: 757-769. 


\section{Appendix 1: Means, standard deviations and factor loadings of the 17 items tapping career orientations on a 7-point scale}

\begin{tabular}{|c|c|c|c|c|c|c|c|c|}
\hline & \multicolumn{8}{|c|}{ factor loadings } \\
\hline & Means & sd & balance & high & free & ahead & no.5 & no.6 \\
\hline reaching the top & 3.27 & 1.92 & & & & .92 & & \\
\hline $\begin{array}{l}\text { acquiring a lot of } \\
\text { power and influence }\end{array}$ & 2.86 & 1.57 & & & & .93 & & \\
\hline $\begin{array}{l}\text { receiving appreciation } \\
\text { and respect }\end{array}$ & 6.29 & 0.79 & & & & & .82 & \\
\hline $\begin{array}{l}\text { being a loyal and } \\
\text { reliable employee }\end{array}$ & 6.00 & 1.10 & & & & & .73 & \\
\hline $\begin{array}{l}\text { having enough time for } \\
\text { work and private life }\end{array}$ & 6.18 & 1.07 & .80 & & & & & \\
\hline $\begin{array}{l}\text { contributing to a bet- } \\
\text { ter world }\end{array}$ & 4.98 & 1.37 & & & & & & .54 \\
\hline $\begin{array}{l}\text { complete autonomy } \\
\text { over my own work }\end{array}$ & 5.07 & 1.43 & & & .86 & & & \\
\hline being my own boss & 4.39 & 1.76 & & & .82 & & & \\
\hline $\begin{array}{l}\text { having the biggest } \\
\text { possible challenge } \\
\text { from work }\end{array}$ & 5.52 & 1.36 & & .69 & & & & \\
\hline $\begin{array}{l}\text { feeling at home in an } \\
\text { organization }\end{array}$ & 6.23 & 0.84 & & & & & & \\
\hline $\begin{array}{l}\text { being able to attain } \\
\text { self-realization }\end{array}$ & 6.30 & 0.92 & & .78 & & & & \\
\hline $\begin{array}{l}\text { creating the right bal- } \\
\text { ance between work, } \\
\text { family, friends and } \\
\text { self-development }\end{array}$ & 6.44 & 0.95 & .78 & & & & & \\
\hline $\begin{array}{l}\text { having a predictable } \\
\text { and secure career } \\
\text { with one organization }\end{array}$ & 3.44 & 1.69 & & & & & & .84 \\
\hline $\begin{array}{l}\text { being creative and in- } \\
\text { novative }\end{array}$ & 5.54 & 1.21 & & .71 & & & & \\
\hline $\begin{array}{l}\text { being independent } \\
\text { from others in my } \\
\text { work }\end{array}$ & 4.45 & 1.48 & & & .67 & & & \\
\hline $\begin{array}{l}\text { harmony between lei- } \\
\text { sure, career and family }\end{array}$ & 6.21 & 1.09 & .90 & & & & & \\
\hline $\begin{array}{l}\text { contributing to organ- } \\
\text { izational goals }\end{array}$ & 5.48 & 1.23 & & & & & .47 & \\
\hline $\begin{array}{l}\% \text { of variance ex- } \\
\text { plained }\end{array}$ & & & 20.3 & 16.3 & 12.3 & 7.2 & 6.9 & 5.4 \\
\hline$\alpha$ & & & .80 & .65 & .73 & .89 & .51 & .40 \\
\hline
\end{tabular}

Factor loadings $<.40$ have been omitted. Variables which have a loading of $>.40$ on more than one factor have been excluded. 